\title{
VALORI TERMINOLOGICE ALE SUBSTANTIVELOR DEVERBALE ROMÂNEȘTI ÎN TEXTELE IMNOGRAFICE ORTODOXE
}

\author{
ECATERINA BRĂGUȚĂ \\ Institutul de Filologie Română „B. P.-Hasdeu” al MEC
}

\begin{abstract}
Rezumat. Studiul nominalizărilor verbale s-a bucurat de o atenție sporită din partea lingviștilor începând cu a doua jumătate a secolului al XX-lea. Aceste unități lexicale, prin natura duală, verbală și nominală, formează o clasă distincte de substantive. Deverbalele înregistrează o frecvență sporită în textul religios, in speță în imnele-acatist. In demersul nostru de inventariere a substantivelor deverbale specifice textelor imnografice românești, am remarcat că o parte dintre unitățile lexicale excerptate aparțin limbajului terminologic creștin. In concordanță cu ideea expusă supra, vom sublinia că in interiorul acatistelor cele mai numeroase substantive deverbale - termeni religioși sunt de origine latină. Acatistele românești conțin numeroși termeni creați prin nominalizare verbală, care pot fi grupați în funcție de câteva sfere de denotare: terminologie festivă; elemente doctrinare; elemente liturgice; elemente ritualistice; terminologia festivă; obiecte de cult.
\end{abstract}

Cuvinte-cheie: substantive deverbale, text religios, imn-acatist, terminologie religioasă, terminologie festivă, terminologie liturgică.

Abstract. The study of verbal nominalizions has enjoyed increasing attention from linguists since the second half of the twentieth century. These lexical units, by their dual, verbal and nominal nature, form a distinct class of nouns. The deverbals register an increased frequency in the religious text, in this case in the akathist hymns. In our approach to the inventory of deverbal nouns specific to Romanian hymnographic texts, we noticed that some of the lexical units excerpted belong to the Christian terminological language. In accordance with the idea set out above, we will emphasize that within the akathists the most numerous deverbal nouns - religious terms are of Latin origin. Romanian akathists contain numerous terms created by verbal nominalizion, which can be grouped according to several spheres of denotation: festive terminology; doctrinal elements; liturgical elements; ritualistic elements; festive terminology; cult objects.

Keywords: deverbal nouns, religious text, hymn-akathist, religious terminology, festive terminology, liturgical terminology.

\section{Terminologia creștină românească}

Terminologia creștină românească este parte componentă a limbajului religios al limbii române, în interiorul căreia se diferențiază trei straturi: latin, 
slav și grec, fiecare dintre straturile amintite mai sus „corespund unui anumit stadiu de evoluție a societății românești sub raportul activității spirituale sau intelectuale." (Onu, 2000, 5).

Interesul lingviștilor pentru acest segment al limbajului religios este probat de o serie de lucrări dedicate terminologiei creștine: Ioan Bălan. Limba cărților bisericești. Studiu istoric și liturgic. Blaj, 1914; Gh. Chivu. Civilizație și cultură. Considerații asupra limbajului bisericesc actual. București, 1997, precum și numeroase articole. În ultimele decenii, eforturile de sistematizare a terminologiei creștine s-au concretizat într-o serie de dicționare și monografii: Stoian I.M. Dicționar religios. Termeni religioși, credințe populare, nume proprii. București, 1994; Mircea I. Dicționar al Noului Testament. București, 1995; Onu Liviu. Terminologia creștină și istoria limbii. București, 2000; Braniște Ene. Dicționar enciclopedic de cunoștințe religioase. Caransebeș, 2001; Teleoacă Dana-Luminița. Terminologia religioasă creștină în limba română. București, 2005; Tat Alin, Sorin Marțian. Dicționar teologic creștin, 2008; Dumas Felicia. Dicționar bilingv de termeni religioși ortodocși, românfrancez. Iași, 2010; Purice Mihail. Terminologia creștină în limba română. Chișinău, 2014.

Prezența termenilor de origine latină este o dovadă a vechimii creștinismului la români. Aceștia redau noțiuni fundamentale de credință creștină și din viața religioasă, demonstrând că ,românii până în secolul al VII-lea au trăit în continuitate trupească și sufletească cu lumea romanică." (Purice, 2014, 18), de asemenea s-a remarcat faptul că rugăciunea „Tatăl nostru" conține $90 \%$ de cuvinte de origine latină (Ibidem, 5). O altă categorie de termeni latini creștini sunt moșteniți prin filieră greacă: biserică blestem, boteza, creștin, inger, Paști, preot.

Terminologia de origine slavă se regăsește în toate domeniile vieții religioase, denumind noțiuni fundamentale ale religiei ortodoxe (moaște, mucenic, pravoslavie); cărți religioase (cazanie, ceaslov, trebnic); sărbători creștine (Blagoveștenie, Ispas, Stretenie); slujbe și ritualuri creștinești (maslu, spovedanie, vecernie. utrenie); trepte ierarhice și funcții (năstavnic, vlădică); vestimentație și obiecte de cult (bederniță, sfeșnic). De asemenea, atestăm o serie de termeni greci, care au pătruns în română prin filieră slavă: chivot, icoană, idol, liturghie, schit, mănăstire, diacon, episcop, sihastru.

Termenii de origine grecească desemnează cărți de cult (Evanghelie, Minei, Octoih, Triod); slujbe și cântări creștine (condac, ectenie, litie); ierarhie bisericească și monahală (arhiereu, călugăr, egumen); termeni arhitecturali (catapeteasmă, amvon, naos, proscomidiar); obiecte de cult (analog, chivot, tricher). Cu toate că o bună parte dintre elenisme au ieșit din uz în secolul al XIX-lea drept consecință a procesului de modernizare a vieții sociale a poporului român, unii termeni au rămas la fel de întrebuințaţi ca și în trecut: afurisi, cimitir, făclie, mărturisi, pizmă, sihastru, schit, turlă. 


\section{Segmentarea pe sfere denotative a terminologiei religioase deverbale din acatistele românești}

În demersul nostru de inventariere a substantivelor deverbale specifice textelor imnografice românești, în special ale acatistelor, am remarcat că o parte dintre unitățile lexicale excerptate aparţin limbajului terminologic creștin. Acatistele românești conțin numeroși termeni creați prin nominalizare verbală (preponderent baze de origine latină). Aceștia pot fi grupați în funcție de câteva sfere de denotare: terminologie festivă; elemente doctrinare; elemente liturgice; elemente ritualistice; terminologia festivă; obiecte de cult.

\section{Terminologie festivă}

Substantivele deverbale actualizează cu succes terminologia festivă ortodoxă, fiind antrenate în procesul de intitulare a actistelor, și se referă la: a) sărbătorile Maicii Domnului: Acoperământul Maicii Domnului, Nașterea Maicii Domnului, Intrarea în Templu a Maicii Domnului; Buna Vestire; Adormirea Maicii Domnului și b) sărbătorile Domnului Iisus Hristos: Nașterea Domnului; Intâmpinarea Domnului; Botezul Domnului; Intrarea în Ierusalim; Invierea Domnului; Schimbarea la față a Domnului; Înălțarea Domnului; c) Pogorârea Sfântului Duh.

\section{Aghionime: nume ale sfinților și ale persoanelor Sfintei Treimi}

Substantivele deverbale comune alcătuiesc masa principală a exemplelor pe care le-am analizat noi. Alături de acestea, remarcăm specializarea mai multor termeni pentru denominarea proprie. Vorbim aici despre nume ale persoanelor Sfintei Treimi, ale Fecioarei Maria sau ale sfinților. Lista de mai jos, însumează cele mai frecvente deverbale - nume proprii, identificate în acatiste:

Atotțiitorul $s . m$. art. Care ține totul; stăpân suprem care poartă grijă făpturilor Sale; Dumnezeu. „Atotțiitorule, Doamne, Cel ce cunoști mulțimile stelelor și la toate le-ai dat nume, Tu singur știi pe nume pe toți cei ce bine Ți-au plăcut Ție” (Ac. Tuturor Sfinților);

Botezătorul s. m. art. Denumirea Sfântului Ioan, ales de Dumnezeu pentru viața sa cea curată să îl boteze pe Hristos în apele Iordanului. „,Se luminează credincioşii de a ta vedere, lăudându-te cu cântări prea mărite, căci ca un rai frumos dumnezeiesc şi stăpânesc, Botezătorule sfinte, înmiresmezi, sfinţind pe cei ce te laudă pe tine cu fierbinţeală şi-ţi cântă aşa" (Ac. Sf. Ioan Botezătorul);

Creatorul s.m.sg. art. (in conceptiile religioase) Dumnezeu. „Creatorul îngerilor te-a ales pe tine..." (Ac. Sf. Cuv. Serafim de Sarov);

Izvorâtor $a d j . \sim$ de mir (loc. adj.). 1. Calitate, însușire a unor sfinți de a face să izvorască din moaștele lor mir frumos mirositor. 2. s. m. art. Nume propriu, de exemplu, Sf. Mc. Dimitrie: ,, Bucură-te, purtător al numelui Marelui Mucenic Dimitrie;// Bucură-te, următor al râvnei sfinte a Izvorâtorului de mir” (Ac. Sf. Dionisie Erhan); 
Înaintemergătorul $s . m$. art. Denumirea sfântului Ioan Botezătorul, trimis de Dumnezeu pentru a pregăti calea și a anunța venirea lui Hristos. „Apostolii te-au preamărit, soborul ierarhilor și al cuvioșilor și ceata sfintelor femei te-au lăudat, Înaintemergătorul și cu Teologul s-au închinat..." (Ac. Sf. Acoperământ);

Mângâietor $a d j ., s . m$. art. Nume dat Duhului Sfânt în rugăciunile creștine. „Vino, Mângâietorule, Duhule Sfinte și te sălașluiește întru noi!” (Ac. Sf. Duh);

Mântuitor s. m.art. Atribut și denumire a lui Hristos, care venit în lume, s-a întrupat, a murit pe cruce și a înviat pentru salvarea neamului omenesc. „Iisuse, Mântuitorule, întăreşte-ne în ispite” (Ac. Sf. Pătimiri);

Născătoare de Dumnezeu $s . f$. Fecioara Maria, mama lui Iisus Hristos. „Bucură-te, cea plină de dar, Născătoare de Dumnezeu Fecioară, bucuria tuturor celor necăjiți” (Ac. MD „Bucuria tuturor celor necăjiți”);

Răscumpărătorul s. m. art. „Răscumpărătorul cel făgăduit” (Ac. Sf. Treimi);

Unul Născut $s . m$. sg. Denumire dogmatică pentru Iisus Hristos, Fiul lui Dumnezeu, care apare în unele imne bisericești. „Unule-Născut, Fiule şi Cuvântul lui Dumnezeu, Cel ce pentru mântuirea noastră ai binevoit a Te intrupa şi moarte a pătimi” (Ac. Sf. Treimi);

Ziditorul s. m. art. Calificativ al lui Dumnezeu-Tatăl, cel ce a zidit cerul și pământul, Creatorul lor. „Ziditorului lumii Celui fără de început” (Ac. Sf. Nicolae).

Nume ale cetelor îngerești

Începătorie $s . f . p l$. Numele uneia dintre cele nouă cete ale îngerilor, care, împreună cu arhanghelii și cu îngerii, alcătuiesc treapta a treia a ierarhiei lor, făcută de Dionisie Areopagitul.

Putere s. $f . p l$. Numele uneia dintre cele nouă cete ale îngerilor, care, împreună cu stăpâniile și domniile, alcătuiesc treapta a doua a ierarhiei lor, făcută de Dionisie Areopagitul. Sunt înfățișați în iconografie desculți, în stihare lungi până la glezne, încinși cu brâu și purtând într-o mână un toiag sau fâșii aurite, iar în cealaltă sigiliul lui Dumnezeu sau globul pământesc: „Arhanghelii și îngerii, începătoriile și puterile, scaunele și domniile, stând inaintea scaunului slavei Tale, nu pot vesti mărimea desăvârșirilor Tale" (Ac. Sf. Treimi).

\section{Nume ale cetelor de sfinți și ale titlurilor acordate de biserică}

Fericit $s$. $m$. Titlu acordat în calendar de Biserica Ortodoxă (ca prim rang al sfințeniei) unor teologi care sunt revendicați de Biserica apuseană, precum fericiții Augustin și Ieronim. (Stoian) Primul grad de sfințenie acordat cuiva de un sinod sau de papă. „Bucura-te, fericite, de minuni făcător” (Ac. Sf. Irh. Alexandru);

Mărturisitor adj., s. m. Cel care Îl mărturisește pe Dumnezeu cu orice preț, dar nu cu cel al vieții. ul (m.). Denumire dată unor sfinți care L-au 
mărturisit pe Hristos și credința creștină, suferind chinuri și schingiuiri, spre exemplu, sfântul Maxim Mărturisitorul. „Bucură-te, Petru, mărturisitorule al Adevărului”; „Săvîrșind sfințita voastră pomenire, cuvioșilor părinți și ierarhi, sfințiți mucenici și mărturisitori, împreună cu ceata sfintelor femei, primiți de la noi această cîntare de laudă, căci toată nădejdea la voi o avem și lui Dumnezeu aducem cîntare: Aliluia!’ (Ac. Sf. Ocrotitori ai Moldovei);

Propovăduitor $a d j ., s . m$. Cel care răspândește credința în Hristos, atribut al apostolilor și al multor sfinți. „Bucură-te, sfinte apostole Simone, propovăduitorule al veșniciei” (Ac. Sf. Ap. Simon);

Răbdător de chinuri $=$ purtător de chinuri $=$ pătimitor $=$ mucenic . „Râvnind ai râvnit pentru dreapta credință a lui Hristos, pe care o aveai pururea in inima ta, răbdătorule de chinuri”; ,pătimitorule al lui Hristos" (Ac. Sf. M. Mc. Dimitrie); „purtătorule de chinuri”" (Ac. Sf. M. Mc. Gheorghe).

\section{Calități creștine}

Desăvârșire $f$. Stare de îmbunătătire și sporire duhovnicească întru apropierea de Dumnezeu. (Stoian) (Sens biblic) Proces sinergetic în care omul conlucrează cu Harul lui Dumnezeu; îndreptare, mântuire, îndumnezeire. „Arhanghelii și îngerii, începătoriile și puterile, scaunele și domniile, stând inaintea scaunului slavei Tale, nu pot vesti mărimea desăvârșirilor Tale" (Ac. Sf. Treimi);

Înainte-vedere $s . f$. „Bucură-te, înainte-vedere a biruinţei dreptei credinţe şi proorocire a căderii vrăjmaşilor ei!" (Ac. Sf. Teodor Studitul);

Neprihănire. s. f. Calitate a ceea ce este fără prihană, fără păcat, fără vină, pur; curățenie, puritate. „Bucurați-vă, Sfinte femei, căci ați dat dovadă de curație sufletească și neprihănire îngerească, căci ați împodobit sufletul cu nenumarate virtuți creștinești, strălucind ca soarele, fiind luminate de frumusețea Chipului lui Dumnezeu, și ați primit darul vindecării trupului și sufletului, precum și darul facerii de minuni" (Ac. Sf. Femei iubitoare de Dumnezeu).

\section{Obiecte liturgice}

Acoperământ $n$. 1. Obiect liturgic ce constă dintr-o bucată de stofă (de același tip cu cea din care sunt lucrate veșmintele liturgice), cu care se acoperă potirul și patena. 2. Batic sau eșarfă cu care femeile își acoperă capul, conform tradiției, când intră în biserică, când participă la slujbe. ,Bucură-te, bucuria noastră, acoperă-ne pe noi de tot răul cu cinstitul tău Acoperământ" (Ac. Acoperământului MD).

\section{Dogmă}

Deșertare $s . f$. (Sens biblic) Dogmă fundamentală a credinței creștine prin care se explică întruparea Fiului lui Dumnezeu (Filip 2, 6-7); chenoză. „Ceea ce ai izvorât Curăţirea vieţii, Izvorul cel nemuritor, Care se deşartă cu deşertare nedeşertată, şi nu se deşertează nicidecum, ci când se deşartă, poezit şi nedeşertat şi plin se arată, Fecioară neispitită de nuntă, vieţii celei fără de moarte învredniceşte-mă" (Canonul Maicii Domnului). 
Întrupare $s . f$. (Bis.) Doctrină de credință promulgată la Sinodul de la Niceea din anul 325 d.Hr., potrivit căreia a doua persoană a Sfintei Treimi, Fiul lui Dumnezeu, ,S-a întrupat de la Duhul Sfânt și din Fecioara Maria și s-a făcut om”. "Iisuse, prin întruparea Ta, trupul nostru cel stricăcios cu nestricăciunea l-ai împodobit" (Ac. Nașterii Domnului nostru Iisus Hristos);

Înviere $s$. $f$. Învierea morților - doctrină introdusă în simbolul de credință de la Constantinopol din anul 381, potrivit căreia toți morții vor învia la judecata de apoi, resuscitare anticipată sacramental în însăși taina botezului. „Sfânt, Sfânt, Sfânt ești Doamne Dumnezeul nostru, Cel ce ai rânduit cu dreaptă judecata Ta nouă tuturor a ne întoarce în pământul din care suntem luați, și în ziua Învierii iarăși a ne scula” (Ac. Sf. Treimi);

Purcedere $s . f$. Acțiunea Duhului Sfânt de a emana, de a-și afla originea la Tatăl. „Vino şi dă-ne nouă să ne împărtăşim de bucuria purcederii Tale” (Ac. Sf. Duh);

Răscumpărare $s . f$. Mântuirea de păcate a omului de către Hristos, prin jertfa Sa pe cruce. ,inţelegând bătrânul sfatul lui Dumnezeu pentru răscumpărarea neamului omenesc, intrând în biserică împreună cu soția sa, cea de Dumnezeu înţelepţită şi închinându-se, a cântat laudă: Aliluia!" (Ac. Sf. Părinți Ioachim și Ana).

\section{Elemente liturgice}

Împărtășanie $s . f$. Cuminecare, consumarea de către preot și credincioși a sfintelor taine, a Trupului și Sângelui lui Hristos; denumirea sfintelor taine. „Iisuse, Cel ce ai înviat din morți și la toate le dai viață, înviază-ne și pe noi, cei omorâți în [...] dă-ne și nouă a Te cunoaște în dumnezeiasca împărtășanie" (Ac. Sf. Învieri);

Priveghere s.f. Slujbă bisericească de noapte, care se săvârşește în mănăstiti și, mai rar, în unele biserici, în ajunul unei sărbători, care cuprinde vecernia și utrenia. „Bucură-te, că prin stările la privegheri ai adormit valurile patimilor" (Ac. Sf. Grigorie Decapolitul).

Denominarea a câteva din cele șapte taine

Botez s.n. (termen grecesc, pătruns prin filieră latină) Prima dintre cele 7 taine creștine, prin care, prin întreita cufundare în apă sfințită, se iartă celui botezat păcatul strămoșesc și păcatele personale săvârșite până atunci (când este vorba de adulți), cei botezați devenind astfel membri ai Bisericii creștine; ritualul prin care se săvârșeșete această taină. ,Deci întru numele a unui Dumnezeu, însă în trei fețe: a Tatălui, a Fiului și a Sfântului Duh, ne-am învățtat a lumina cu Botezul pe tot omul ce vine în lume cîntând: Aliluia!' (Ac. Sf. Treimi);

Mărturisire $s . f$. Una dintre cele șapte taine creștine, prin care credinciosul, în urma mărturisirii păcatelor înaintea preotului duhovnic, obține iertarea păcatelor săvârșite după botez sau după o altă mărturisire, precum și 
împăcarea cu Dumnezeu și cu Biserica; spovedanie. „Bucură-te, doctor de suflete şi călăuză spre mărturisirea curată" (Ac. Sf. Nicodim Aghioritul);

Pocăință $s . f$. 1. Părere de rău, căință pentru păcatele făcute. 1. Denumire pentru taina spovedaniei, a mărturisirii păcatelor și greșelilor făcute în fața unui duhovnic, însoțită de o căință sinceră și profundă. „Bucură-te, ridicarea celor căzuți la pocăință” (Ac. Sf. Gavriil Bănulescu-Bodoni).

\section{Elemente de rit}

Adormire s. $f$. Cuvânt folosit în ortodoxie ca sinonim pentru moarte, deoarece moartea este considerată ca o adormire ce precede învierea. „Lumină strălucitoare fiind în viaţă, de Dumnezeu fericite părinte, după adormirea ta ai răsărit ca o lumină strălucitoare pământului nostru, că verşi de la cinstitele tale moaşte curgeri de minuni şi ajuţi tuturor celor, ce cu credinţă şi cu dragoste aleargă către tine". (Ac. Cuv. Macarie de la Saharna);

Ardere-de-tot-jertfă care spre deosebire de cele obișnuite (de împăcare, pentru păcat, de curățire, de mulțumire etc.), era adusă prin arderea integrală a animalului și era considerată în Vechiul Testament ca „o mireasmă bună înaintea Domnului”. „Bucurați-vă, că ardere de tot v-ați adus” (Ac. Sfinților Români);

Ascultare $s . f$. 1. Supunere față de o autoritate, de stareț în cazul monahilor, urmarea întocmai şi respectarea sfaturilor unui părinte duhovnic. 2. Numele sarcinii pe care monahul sau monahia o au de îndeplinit la mănăstire. ,şi ai arătat multă râvnă la ascultarea încredințată ție de a semăna tinerilor invățăturile cele folositoare" (Ac. Sf. Irh. Gavriil Bănulescu-Bodoni);

Binecuvântare s.f. 1. Rugăciune de invocare a ajutorului și a harului lui Dumnezeu pentru sfințirea unei persoane sau a unui lucru. 2. Gestul preotului făcut cu mâna dreaptă (sau/și cu crucea asupra credincioșilor în timpul slujbelor și mai ales al liturghiei euharistice) și al arhiereului făcut cu ambele mâini (sau/şi cu dicherul și tricherul) tot asupra credincioşilor la slujbele arhierești. „Bucură-Te, ceea ce ești binecuvântare și bucurie astfel ne dăruiești” (Ac. MD „Sporitoarea minții”);

Dreptmăritor adj., s. m. Sinonim pentru ortodox. „Aparatorului credinței dreptmăritorilor, Cuviosului Părintelui nostru Spiridon, să-i aducem din inima mărturisiri mulțumitoare..." (Ac. Sf. Spridon);

Ispită $s . f$. Tentație, îndemn spre rău, spre săvârșirea păcatului; încercare. „Bucură-te, că amară temniță ai răbdat;// Bucură-te, că în ispite nu ai cedat" (Ac. Sf. Irh. Gavriil Bănulescu-Bodoni);

Înfrânare $s . f$. Acțiunea de a se înfrâna, de a se abține de la lucruri şi fapte care nu sunt folositoare pentru viața duhovnicească. „Bucură-te, căci cu plugul înfrânării ai arat pământul sufletului tău" (Ac. Sf. Grigore Decapolitul); „Cu înfrânare aspră te-ai încins şi petrecând multă vreme ca 
unul lepădat de lume, cu inimă arzândă de focul dorului dumnezeiesc, te rugai pentru pacea lumii" (Ac. Sf. Maxim Kavsokalivitul);

Laudă s. f. 1. Elogiu, cântare de preamărire aduse lui Dumnezeu. 2. Preamărire, acțiunea de a-L slăvi pe Dumnezeu cel în Treime. (s. n.). Tip de rugăciune prin care se aduce slavă și laudă lui Dumnezeu în Treime, mai ales la biserică, dar poate fi și personală. „Pentru aceea laude ca acestea aducem ție: Bucură-te, că te-ai învrednicit a fi al turmei lui Hristos păstor nebiruit" (Ac. Sf. Mc. Ciprian);

Mijlocire $s . f$. Intervenție, mediere, acțiune realizată de Maica Domnului și de sfinţi pe lângă Hristos, pentru credincioși, la cererea acestora. „Bucurăte, ceea ce izbăveşti lumea din necazuri cu mijlocirile tale” (Ac. MD „Bucuria tuturor necăjiţilor);

Nevoință $s . f$. Asceză, strădanie duhovnicească ce constă mai cu seamă în post și rugăciune, practicată în special de călugări, de cei care au ajuns la sfințenie. „Bucură-te, că nevoința pustniciei cu mare dragoste o ai primit”" (Ac. Sf. Cuv. Teodora de la Sihla);

Odihnă $s$. $f$. Termen folosit pentru moarte, odihna de veci. „Iar când te-a chemat pe tine Domnul de la ostenelile cele pământești la odihna cea cerească, niciodată dragostea ta n-a lipsit de la noi" (Ac. Sf. Serafim de la Sarov);

Pomenire $s . f$. 1.Amintire duhovnicească plăcută. 2. Amintirea vieții sfinţilor comemorați în zilele anului bisericesc, conform rânduielilor din calendar și Sinaxar. 3. Slujbă religioasă pentru cei morți. „Har bogat izvorăști, fericită Eufrosina, peste cei care cinstesc pomenirea ta și aleargă la acoperamântul tău" (Ac. Sf. Eufrosina);

Propovăduires. $f$. Vestireașirăspândireaînvățăturii creștine, predicare. „Ca un nou apostol, de Dumnezeu fiind trimis la propovăduire, degrab ai smuls din rădăcină spinii relei credinţe, şi arând ogorul inimilor cel înţelenit al credincioşilor, ai semănat dumnezeiasca sămânță care în inimile noastre a răsărit ..." (Ac. Sf. Fotie);

Proslăvire $s . f$. Adorare, preamărire a lui Dumnezeu sau a sfinților. „Lăudând proslăvirea ta, te fericim toți credincioşii, Cuvioase Părinte Stelian, lauda Bisericii şi podoaba monahilor..." (Ac. Sf. Stelian);

Slujitor $s . m$. Denumirea preotului, în calitatea sa de cel care îl slujește pe Dumnezeu. „Bucură-te, slujitor vrednic al altarului preasfânt” (Ac. Sf. M. Mc. Carp);

Venire $s . f$. Cea de a doua $\sim$ a lui Hristos Momentul Parusiei, când Hristos va reveni pe pământ la sfârșitul timpurilor, ca Împărat și Judecător, marcând începutul Împărăţiei sale veșnice. „Bucură-te, c $\breve{a}$ bătrânul a postit 40 de zile și rugându-se a auzit glas din cer: Că aşa se va munci până la a doua venire" (Ac. Sf. Paisie cel Mare);

Viețuitor, viețuitoare $s . m$., s. f. Membrii ai unui așezământ monahal, 
călugării și călugărițe. „Bucură-te, ocrotitorul și ajutătorul viețuitorilor Mănăstirii Secu" (Ac. Sf. Siluan Athonitul);

Zăvorâre $s$. $f$. Mod de vițuire al unui monah, care presupune izolarea benevolă în chilia unei mănăstiri. „purtând jugul vieții pustnicești al zăvorârii, al tăcerii și al privegherii de multe nopți”" (Ac. Sf. Serafim de la Sarov).

Concluzii: Luând în considerare exemplele enumerate mai sus și contextele lor de utilizare, ajungem la următoarea concluzie: substantivele deverbale identificate în acatistele românești actualizează o serie de termeni specifici creștinismului ortodox. Clasificarea semantică a acestora demonstrează predilecția lor pentru: terminologie festivă, denominarea Dumnezeirilor și a creaturilor netrupești, termeni liturgici, termeni dogmatici, termeni care țin de rit, obiecte de cult (acoperământ). Stratul terminologic latin (includem aici și termeni deverbali formați de la o bază verbală de origine latină) este predominant. Cea mai mare parte a termenilor creștini deverbali sunt caracterizați de trăsătura [+Abstract], definitorie pentru infinitivul lung. Unii termeni deverbali au evoluat semantic, migrând din categoria substantivelor comune spre cele proprii: Botezătorul, Izvorâtorul de mir, Inaintemergătorul, Născătoare de Dumnezeu, Unul-Născut, precum și numele-atribute ale Dumnezeirii: Creatorul, Făcătorul, Judecătorul, Mângâietorul, Răscumpărătorul.

\section{Referințe bibliografice:}

1. BĂLAN, Ioan. Limba cărților bisericești. Studiu istoric și liturgic. Blaj: Tipografia Seminarului teologic Greco-catolic, 1914.

2. CHIVU, Gheorghe. Civilizație și cultură. Considerații asupra limbajului bisericesc actual. București: Editura Academiei Române, 1997.

3. DUMAS, Felicia. Dicționar bilingv de termeni religioși ortodocși, românfrancez. Iași, 2010.

4. ONU, Liviu. Terminologia creștină și istoria limbii române. București: Editura Academiei Române, 2000. 2014.

5. PURICE, Mihail. Terminologia creștină în limba română. Chișinău: CEP USM,

6. STOIAN, I.M. Dicționar religios. Termeni religioși, credințe populare, nume proprii. București, 1994;

7. TELEOACĂ, Dana-Luminița. Terminologia religioasă creștină în limba română. București, 2005.

Notă: Articolul a fost realizat în cadrul proiectului de cercetare 20.80009.1606.01 Valorificarea științifică a patrimoniului lingvistic național în contextul integrării europene, Institutul de Filologie Română „B. P.-Hasdeu” al MEC. 